\title{
Karakterisasi Mineral Magnetik Sedimen Sungai Citarum Hilir Melalui Analisis Sifat Magnetik, Mineralogi serta Morfologi Magnetik
}

\author{
Kartika Hajar Kiranaa,b* , Mechdi Ghazalia, Luh Ayu Eka Safitri Septianaa, Dini Fitriania,b, Eleonora
}

Agustine $^{\mathrm{a}, \mathrm{b}}$, Silvia Jannatul Fajarc, Muhamad Gina Nugraha ${ }^{\mathrm{d}}$

aDepartemen Geofisika, Fakultas Matematika dan Ilmu Pengetahuan Alam, Universitas Padjadjaran, Jalan

Raya Bandung-Sumedang Km. 21 Jatinangor 45363

${ }^{\mathrm{b}}$ Centre of Citarum Research, Universitas Padjadjaran, Jalan Raya Bandung-Sumedang Km. 21 Jatinangor 45363

cFakultas Teknik Pertambangan dan Perminyakan, Institut Teknologi Bandung, Jalan Ganesa Nomor 10 Bandung, 40132

${ }^{d}$ Departemen Pendidikan Fisika, Fakultas Pendidikan Matematika dan Ilmu Pengetahuan Alam, Universitas Pendidikan Indonesia, Jalan Dr. Setiabudhi 229 Bandung, 40152

*Email : kartika@geophys.unpad.ac.id

(Diterima 3 September 2020; Disetujui 16 Desember 2020; Dipublikasikan 29 Desember 2020)

\begin{abstract}
Abstrak
Sungai Citarum merupakan sungai utama yang ada di Provinsi Jawa Barat yang sangat penting bagi kehidupan sosial dan ekonomi. Di bagian hilir, Sungai Citarum ini banyak melewati daerah pemukiman padat penduduk, daerah industri, dan bahkan pesawahan. Oleh karena itu, perlu kajian mengenai kondisi Sungai Citarum salah satunya dengan mengidentifikasi parameter electrical conductivity (EC), total dissolve solid (TDS), pH dan suhu serta karakteristik mineral magnetik pada sedimen melalui analisis sifat magnetik, mineralogi dan morfologi magnetiknya. Pengukuran parameter EC, TDS, pH dan suhu dilakukan secara in situ pada sampel air Sungai Citarum, pengukuran sifat magnetik dilakukan pada sampel sedimen yang telah dipreprasi, sedangkan pengukuran mineralogi dan morfologi dilakukan pada sampel sedimen yang telah diekstraksi. Sifat magnetik sedimen diketahui dari nilai suseptibilitas magnetik dual frekuensi yang diukur menggunakan Bartington Magnetik Susceptibilitymeter, sedangkan mineralogi dan morfologi magnetik diketahui berdasarkan hasil pengukuran scanning electron microscope-energy disperdsive $x$-ray (SEM-EDS) dan x-ray diffractometer (XRD). Hasil pengukuran secara in situ pada sampel air menunjukkan bahwa rentang nilai EC, TDS, pH dan suhu berturut-turut adalah (200-4120) $\mu \mathrm{S} / \mathrm{cm},(100-2060) \mathrm{ppt}, 7,34-9,22$, dan $(26,8-32,6){ }^{\circ} \mathrm{C}$. Sedangkan, hasil pengukuran sifat magnetik menunjukkan bahwa sampel sedimen Sungai Citarum bagian hilir memiliki nilai suseptibilitas magnetik frekuensi rendah $\left(\chi_{\mathrm{LF}}\right)$ dengan rentang $(65,00-173,80) \times 10^{-8} \mathrm{~m}^{3} / \mathrm{kg}$, sedangkan rentang nilai suseptibilitas magnetik frekuensi tinggi $\left(\chi_{\mathrm{HF}}\right)$ adalah $(64,90-165,70) \times 10^{-8} \mathrm{~m}^{3} / \mathrm{kg}$. Dari kedua pengukuran $\chi_{\mathrm{LF}}$ dan $\chi_{\mathrm{HF}}$ diperoleh rentang nilai $\chi_{\mathrm{FD}}(\%)$ sebesar $0,15-4,66$. Selanjutnya, hasil analisis morfologi dari citra SEM-EDS dan analisis mineralogi berdasarkan pengukuran XRD menunjukkan dominasi jenis mineral magnetik pada sampel sedimen adalah magnetit. Mineral magnetit ini memiliki morfologi berbentuk oktahedral sebagai representasi mineral magnetik alami dan ada pula yang berbentuk spherule sebagai representasi mineral magnetik karena adanya proses oksidasi akibat kehadiran material antropogenik pada sedimen Sungai Citarum bagian hilir.
\end{abstract}

Kata kunci: Sungai Citarum, suseptibilitas magnetik, morfologi, mineralogi, mineral magnetik

\section{Latar Belakang}

Sungai Citarum merupakan sungai terpanjang yang ada di Provinsi Jawa Barat dengan panjang mencapai $\pm 300 \mathrm{~km}$. Sebagai sungai utama di Jawa Barat, air Sungai Citarum banyak dimanfaatkan, misalnya sebagai sumber air oleh Perusahaan Daerah Air Minum (PDAM), pembangkit listrik tenaga air (PLTA) serta irigasi lahan pertanian. Namun, Sungai Citarum kini memerlukan perhatian khusus dari berbagai seiring dengan penurunan kondisi lingkungan yang terjadi, yaitu adanya pencemaran. Pencemaran tersebut dapat terlihat dari profil data biological oxygen demand (BOD), chemical oxygen demand (COD) dan dissolve oxygen (DO) pada sampel air Sungai Citarum yang tidak memenuhi standar baku mutu air bersih [1]. Selain itu, adanya kandungan logam berat timbal $(\mathrm{Pb})$ dan cadmium (Cd) pada kolom air dan sedimen Sungai Citarum menambah permasalahan pencemaran di Sungai Citarum [2]. Salah satu ciri lain adanya penurunan kondisi lingkungan di Sungai Citarum adalah sedimentasi [3].

Sedimen Sungai Citarum diketahui memiliki kelimpahan mineral magnetik yang tinggi [4], sedangkan kelimpahan mineral magnetik ini dapat dijadikan sebagai salah satu indikator pencemaran $[5,6]$. Kelimpahan mineral magnetik pada sedimen 


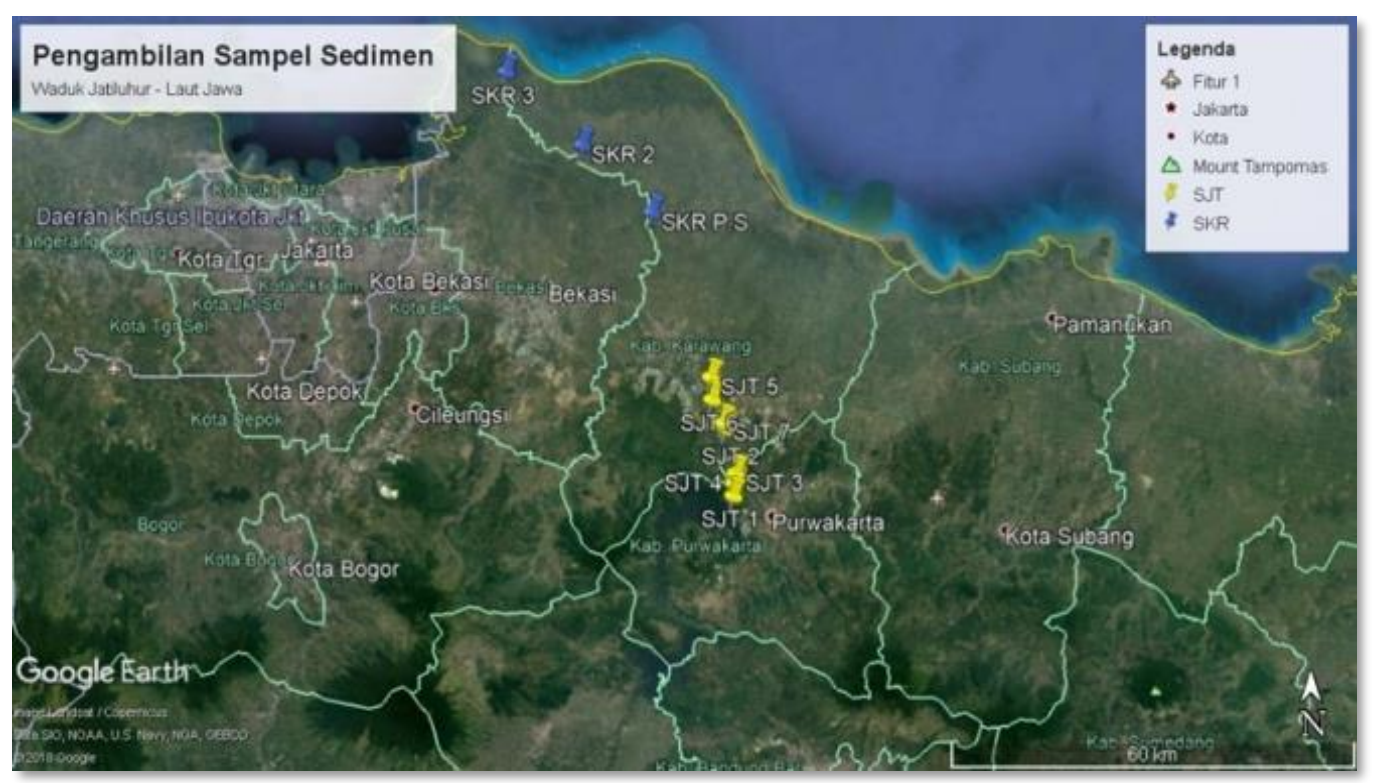

Gambar 1. Pin berwarna kuning dan biru menunjukkan lokasi pengambilan sampel sedimen dari Waduk Jatiluhur sampai dengan Laut Jawa.

berasal dari dua sumber berbeda, yaitu litogenik dan antropogenik [7]. Material litogenik berasal dari pelapukan batuan asal, sedangkan material antropogenik berasal dari aktivitas manusia, seperti limbah industri, perternakan, dan perkebunan, hingga asap kendaraan bermotor [8].

Beberapa studi mengenai karakterisasi mineral magnetik pada sedimen di Daerah Aliran Sungai (DAS) Citarum telah dilakukan, yaitu studi mengenai pencemaran yang terjadi di DAS Citarum bagian hulu dengan mengidentifikasi korelasi antara parameter magnetik dengan kandungan logam berat [4]. Selain itu, terdapat studi yang menganalisis kelimpahan mineral magnetik dan potensi pencemaran yang terjadi pada DAS Citarum di Kabupaten Karawang [9]. Berdasarkan dua studi tersebut dikatakan bahwa adanya kelimpahan mineral magnetik yang tinggi diduga berasal dari material antropogenik [9] dan sedimen yang banyak mengandung material antropogenik memiliki kandungan logam berat yang tinggi [10-12] yang berasosiasi dengan kelimpahan mineral magnetik yang tinggi pula. Namun, penelitian yang dilakukan di DAS Citarum hilir sebatas hanya di daerah Kabupaten Karawang, tidak mencakup seluruh DAS Citarum hilir, yaitu mulai dari Waduk Jatiluhur hingga ke Pulau Jawa.

Oleh karena itu, pada penelitian ini, hal yang dilakukan adalah mengidentifikasi karakterisasi mineral magnetik pada sedimen di Sungai Citarum hilir, mulai dari Waduk Jatiluhur hingga ke Pulau Jawa melalui analisis sifat magnetik, morfologi, dan mineraloginya didukung dengan pengukuran parameter secara insitu (EC, TDS, pH dan suhu) sebagai analisis awal kondisi Sungai Citarum hilir.
Karakterisasi mineral magnetik banyak digunakan untuk kajian mengenai pencemaran $[7,13,14]$. Sifat magnetik adalah sebagai indikator proksi dari pencemaran [15] dan parameter kunci untuk menunjukkan kondisi formasi fase magnetik dan atau proses seperti diagenesis dan pelapukan [16]: Sifat magnetik dari sedimen dapat diketahui berdasarkan nilai suseptibilitas magnetiknya, sedangkan mineralogi dan morfologi dianalisis berdasarkan bentuk bulir magnetik dan jenis mineral magnetik yang terdapat pada sedimen. Dengan dilakukannya karakterisasi mineral magnetik pada sedimen, diharapkan dapat digunakan sebagai monitoring kondisi lingkungan di Sungai Citarum.

\section{Metodologi}

Sebelum dilakukan pengambilan sampel sedimen dari DAS Citarum, terlebih dahulu dilakukan pengukuran parameter fisis dan kimia air Sungai Citarum di setiap lokasi pengambilan sampel secara in situ menggunakan Hanna Combometer. Pengukuran ini terdiri dari parameter Electrical Conductivity (EC) yang merupakan ukuran kapasitas cairan untuk menghantarkan muatan listrik [17], kemudian pengukuran konsentrasi ion terlarut atau Total Dissolve Solid (TDS), pH dan suhu.

Penelitian ini menggunakan sampel sedimen yang berasal dari DAS Citarum bagian hilir, yaitu mulai dari Waduk Jatiluhur hingga mendekati Pulau Jawa. Gambar 1 menunjukkan lokasi pengambilan sampel. Lokasi pengambilan sampel ini didasarkan pada akses jalan yang tersedia ketika proses pengambilan sampel. Jumlah sampel yang diambil 
dari Waduk Jatilihur sampai dengan Bendungan Walahar sebanyak delapan sampel sedangkan sampel yang diambil dari Rengasdengklok sampai dengan Laut Jawa sebanyak tiga sampel.

Preparasi sampel dimulai dengan melakukan sieving (ayak) terhadap sampel sedimen menggunakan mesh 325 (ukuran lempung) agar didapatkan bentuk bulir yang homogen. Pengayakan dilakukan dengan metode ayak basah [18]. Setelah didapatkan sampel hasil ayak, maka selanjutnya dimasukkan ke dalam holder dengan volume $10 \mathrm{~cm}^{3}$ untuk menjalani pengukuran suseptibilitas magnetik. Pengukuran suseptibilitas magnetik dilakukan menggunakan Bartington MS2B Susceptibility Meter Dual Frequency, yaitu $470 \mathrm{~Hz}$ untuk frekuensi rendah dan $4700 \mathrm{~Hz}$ untuk frekuensi tinggi. Pengukuran suseptibilitas magnetik frekuensi rendah dan frekuensi tinggi dilakukan pada setiap sampel, masing-masing sebanyak lima kali pengulangan. Hasil yang diperoleh dari pengukuran ini adalah suseptibilitas magnetik frekuensi rendah $\left(\chi_{\mathrm{LF}}\right)$ dan suseptibilitas magnetik frekuensi tinggi $\left(\chi_{\mathrm{HF}}\right)$. Persentase dari selisih antara suseptibilitas magnetik frekuensi rendah dan suseptibilitas magnetik frekuensi tinggi disebut suseptibilitas magnetik bergantung frekuensi $\chi_{\mathrm{FD}}(\%)=\left[\left(\chi_{\mathrm{LF}}-\chi_{\mathrm{HF}}\right) / \chi_{\mathrm{LF}}\right] \times 100 \%$. Suseptibilitas magnetik bergantung frekuensi dapat menunjukkan kandungan mineral superparamagnetik pada sampel [19].

Selanjutnya, dilakukan ekstraksi sampel dengan menggunakan magnetic stirrer untuk memisahkan mineral magnetik dari pengotornya (biasanya berupa lempung) [20]. Setelah didapatkan sampel hasil ekstraksi kemudian dilakukan pengukuran scanning electron microscope (SEM) menggunakan JEOL JSM-6510A dan energy dispersive spectroscopy (EDS) menggunakan JED-2300 Analysis Station. Pengukuran SEM dan EDS digunakan untuk mengidentifikasi morfologi mineral magnetik dan melihat pemetaan unsur yang terdapat pada sampel sedimen. Setelah itu, dilakukan pengukuran X-Ray Diffractometer (XRD) menggunakan SmartLab X-Ray Diffractometer Rigaku. Analisis mineralogi pada sampel sedimen diidentifikasi melalui pengukuran XRD.

\section{Hasil dan Pembahasan}

Hasil pengukuran in situ parameter EC, TDS, pH dan suhu terhadap sampel air ditampilkan pada Tabel 1. Rentang nilai EC, TDS, pH dan suhu berturut-turut adalah (200-4120) $\mu \mathrm{S} / \mathrm{cm},(100-$ 2060) ppt, 7,34-9,22, dan $(26,8-32,6){ }^{\circ} \mathrm{C}$.

Nilai EC dan TDS sering digunakan sebagai parameter kualitas air [21]. Kualitas air yang baik memiliki nilai EC di bawah $1500 \mu \mathrm{S} / \mathrm{cm}$ dan nilai TDS kurang dari $1000 \mathrm{mg} / \mathrm{L}$ [22]. Selanjutnya, menurut Peraturan Menteri Kesehatan Republik
Indonesia Tahun 2017, air bersih memiliki $\mathrm{pH}$ antara 6,5 - 8,5 dan suhu di bawah $30^{\circ} \mathrm{C}$ [23].

Secara umum, nilai rata-rata TDS sampel air DAS Citarum Hilir adalah 352,60 mg/L. Nilai ini berada di bawah ambang batas yang diizinkan. Anomali terhadap nilai TDS berada pada sampel SKR 3. Sampel SKR 3 berada di dekat Laut Jawa sehingga tingginya nilai TDS dikarenakan karena pengaruh air laut yang bersifat salin. Selain TDS, pH dan suhu dari sampel air DAS Citarum menunjukkan nilai yang berada dalam rentang standar Permenkes. Demikian pula dengan parameter EC. Nilai rata-rata EC dari sampel adalah sebesar 720,70 $\mu \mathrm{S} / \mathrm{cm}$, yang mana masih di bawah ambang batas kualitas air yang baik kecuali pada sampel SKR3. Mengingat sampel SKR3 ini merupakan anomali, ditinjau dari tingginya nilai EC dan TDS karena bersifat salin, maka untuk pengukuran selanjutnya, sampel SKR3 tidak menjalani pengukuran lebih lanjut.

Tabel 1. Hasil pengukuran parameter fisika dan kimia sampel air DAS Citarum Hilir

\begin{tabular}{|c|r|r|r|r|}
\hline $\begin{array}{c}\text { Nama } \\
\text { Sampel }\end{array}$ & $\begin{array}{c}\text { EC } \\
(\boldsymbol{\mu} \mathbf{S} / \mathbf{c m})\end{array}$ & $\begin{array}{c}\text { TDS } \\
(\mathbf{m g} / \mathbf{L})\end{array}$ & $\mathbf{p H}$ & $\begin{array}{c}\text { Suhu } \\
\mathbf{( C )}\end{array}$ \\
\hline SJT P.S & 200 & 100 & 9,22 & 27,0 \\
\hline SJT 2 & 210 & 105 & 7,48 & 26,8 \\
\hline SJT 3 & 208 & 104 & 7,34 & 26,8 \\
\hline SJT 4 & 379 & 118 & 8,58 & 28,3 \\
\hline SJT 5 & 287 & 143 & 8,25 & 29,1 \\
\hline SJT 7 & 256 & 128 & 8,00 & 28,2 \\
\hline SJT 8 & 257 & 128 & 7,74 & 27,6 \\
\hline SKR P.S & 570 & 280 & 7,80 & 29,6 \\
\hline SKR 2 & 720 & 360 & 8,00 & 31,3 \\
\hline SKR 3 & 4120 & 2060 & 8,15 & 32,6 \\
\hline
\end{tabular}

Pengukuran terhadap sampel sedimen dilakukan pada tujuh sampel. Hasil pengukuran suseptibilitas magnetik (Tabel 2.) menunjukkan bahwa rentang nilai $\chi_{\text {LF }}$ adalah $(65,00-173,80) \times$ $10^{-8} \mathrm{~m}^{3} / \mathrm{kg}$, dengan rata-rata sebesar $111,59 \times 10^{-8}$ $\mathrm{m}^{3} / \mathrm{kg}$. Sedangkan rentang nilai $\chi_{\mathrm{HF}}$ adalah $(64,90-$ $165,70) \times 10^{-8} \mathrm{~m}^{3} / \mathrm{kg}$, dengan rata-rata sebesar $108,39 \times 10^{-8} \mathrm{~m}^{3} / \mathrm{kg}$. Dari kedua pengukuran $\chi_{\mathrm{LF}}$ dan $\chi_{\mathrm{HF}}$ diperoleh rentang nilai $\chi_{\mathrm{FD}}(\%)$ sebesar $0,15-$ 4,66, dengan rata-rata sebesar 2,55.

Tabel 2. Pengukuran Nilai Suseptibilitas Magnetik Sungai Citarum

\begin{tabular}{|c|c|c|c|}
\hline $\begin{array}{l}\text { Nama } \\
\text { Sampel }\end{array}$ & $\begin{array}{c}\chi_{\mathrm{LF}}\left(\times 10^{-8}\right. \\
\left.\mathrm{m}^{3} / \mathrm{kg}\right)\end{array}$ & $\begin{array}{c}\chi_{\mathrm{HF}}\left(\times 10^{-8}\right. \\
\left.\mathrm{m}^{3} / \mathrm{kg}\right)\end{array}$ & $\begin{array}{l}\chi \text { FD } \\
(\%)\end{array}$ \\
\hline SJT P.S & 147,50 & 146,20 & 0,88 \\
\hline SJT 2 & 89,80 & 87,10 & 2,34 \\
\hline SJT 4 & 173,80 & 165,70 & 4,66 \\
\hline SJT 5 & 141,50 & 136,70 & 3,39 \\
\hline SJT 7 & 89,00 & 85,10 & 4,38 \\
\hline SKR P.S. & 65,00 & 64,90 & 0,15 \\
\hline SKR 2 & 74,50 & 73,00 & 2,05 \\
\hline
\end{tabular}




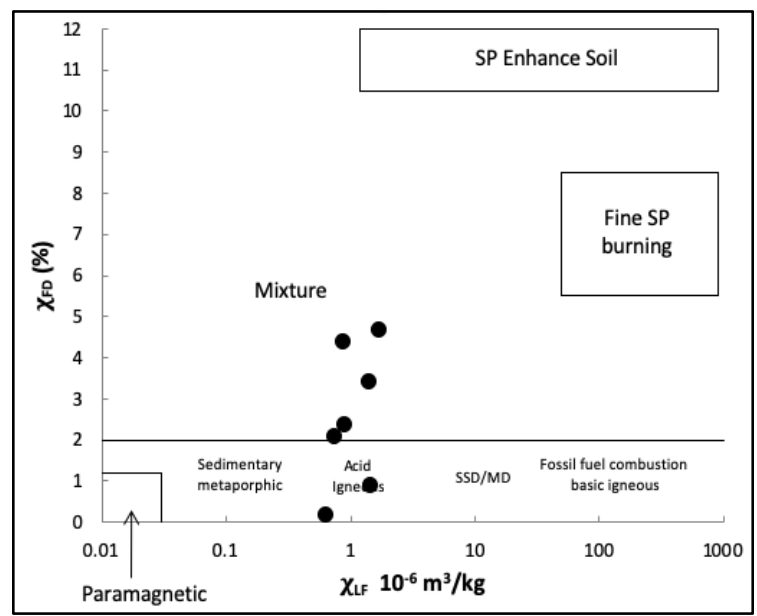

Gambar 2. Diagram $\chi_{\mathrm{LF}}$ terhadap $\chi_{\mathrm{FD}}(\%)$ menunjukkan sumber dari keberadaan bulir superparamagnetik pada sampel.

Nilai $\chi_{\mathrm{FD}}(\%)$ yang kurang dari $2 \%$ termasuk kategori low $\chi_{\mathrm{FD}}(\%)$ [15] dan sampel ini memiliki bulir nonsuperparamagnetik dengan bulir berukuran $>0,03 \mu \mathrm{m}$ yang terdapat pada sampel SJT P.S dan SKR P.S. Sampel yang berada pada nilai 2,0 $10,0 \%$ termasuk kategori medium $\chi_{\mathrm{FD}}(\%)$ sampel ini mengandung campuran bulir superparamagnetik dengan bulir berukuran $<0,005 \mu \mathrm{m}$ yang terdapat pada sampel SKR 2, SJT 2, SJT 4, SJT 5, dan SJT 7. Bulir superparamagnetik merupakan mineral dengan ukuran bulir yang sangat halus (lebih kecil dari $\sim 0,03 \mu \mathrm{m}$ ) dan memiliki perilaku magnetik yang memperlihatkan perubahan terhadap waktu seperti pada sampel sedimen Sungai Citarum bagian hilir. Bulir magnetik alami (litogenik) sebagian besar merupakan bulir superparamagnetik [24]. Pada sedimen yang tercemar oleh polutan (antropogenik) sering ditemukan nilai $\chi_{\mathrm{FD}}$ (\%) rendah (1-4\%), sedangkan tanah yang mengalami proses secara alami atau litogenik memiliki nilai $\chi_{\mathrm{FD}}(\%)$ yang lebih tinggi ( $>10 \%$ ) [25].

Hubungan $\chi_{\mathrm{LF}}-\chi_{\mathrm{FD}}(\%)$ dapat membantu membedakan antara ukuran bulir dengan status domain serta memberikan informasi mengenai klasifikasi sifat magnetik dan sumbernya [19]. Pada Gambar 2 berdasarkan diagram $\chi_{\mathrm{LF}}-\chi_{\mathrm{FD}}(\%)$ menunjukkan bahwa pada sedimen permukaan Sungai Citarum bagian hilir terdapat sampel yang merupakan berasal dari bulir dasar dari batuan beku, namun adapula yang telah mengalami perubahan. Hal ini dikarenakan sampel yang diambil di Sungai Citarum bagian hilir ini meliputi daerah Waduk Jatiluhur, daerah industri, daerah pemukiman penduduk, dan daerah yang jauh dari pemukiman (dekat ke Laut Jawa), sehingga sampel dapat merekam mineral magnetik pembawa polutan. Mineral magnetik hasil pembakaran akan memiliki bentuk bulir yang berbeda dengan bentuk bulir mineral magnetik alami. Bentuk mineral magnetik (morfologi) akan diketahui dengan pengukuran SEM.

Berdasarkan hasil pengukuran sifat fisika dan kimia, termasuk pengukuran suseptibilitas magnetik, dapat diperoleh informasi menarik seperti yang ditunjukkan oleh Gambar 3. Semakin ke titik ujung tempat pengambilan sampel (semakin ke hilir), nilai EC dan TDS semakin besar, sedangkan nilai $\chi_{\mathrm{LF}}$ semakin kecil. EC dan TDS akan memiliki nilai yang besar pada daerah salin [21], sedangkan besar kecilnya nilai $\chi_{\mathrm{LF}}$ bergantung pada batuan dasar daerah pengambilan sampel dan tingkat pencemaran [18]. Umumnya nilai $\chi_{L F}$ yang tinggi berasosiasi dengan tingkat pencemaran yang tinggi pula, sebaliknya, nilai $\chi_{\mathrm{LF}}$ rendah berarti bahwa tingkat pencemaran yang rendah. Penelitian mengenai $\chi_{\mathrm{LF}}$ sebagai indikator proksi dari pencemaran di daerah Sumbawa menjelaskan bahwa daerah tercemar memiliki $\chi_{L F}$ yang lebih besar daripada $\chi_{\text {LF }}$ pada daerah yang tidak tercemar [26]. Selain itu, hal yang sama ditunjukkan melalui studi di Sungai Ponnaiyar India [27]. Namun hal tersebut ternyata tidak terjadi pada sedimen Sungai Citarum hilir. Dengan demikian, harus dianalisis bagaimana pengaruh batuan dasar sekitarnya yang berpengaruh terhadap nilai $\chi_{\mathrm{LF}}$ yang besar. Pada Sungai Citarum hulu, nilai $\chi_{\mathrm{LF}} \mathrm{di}$ bagian yang terdekat dengan Km 0 Sungai Citarum memiliki nilai $\chi_{\mathrm{LF}}$ yang lebih besar dibandingkan dengan nilai $\chi_{\mathrm{LF}}$ pada bagian bawah Sungai Citarum hulu yang menunjukkan nilai yang lebih kecil,

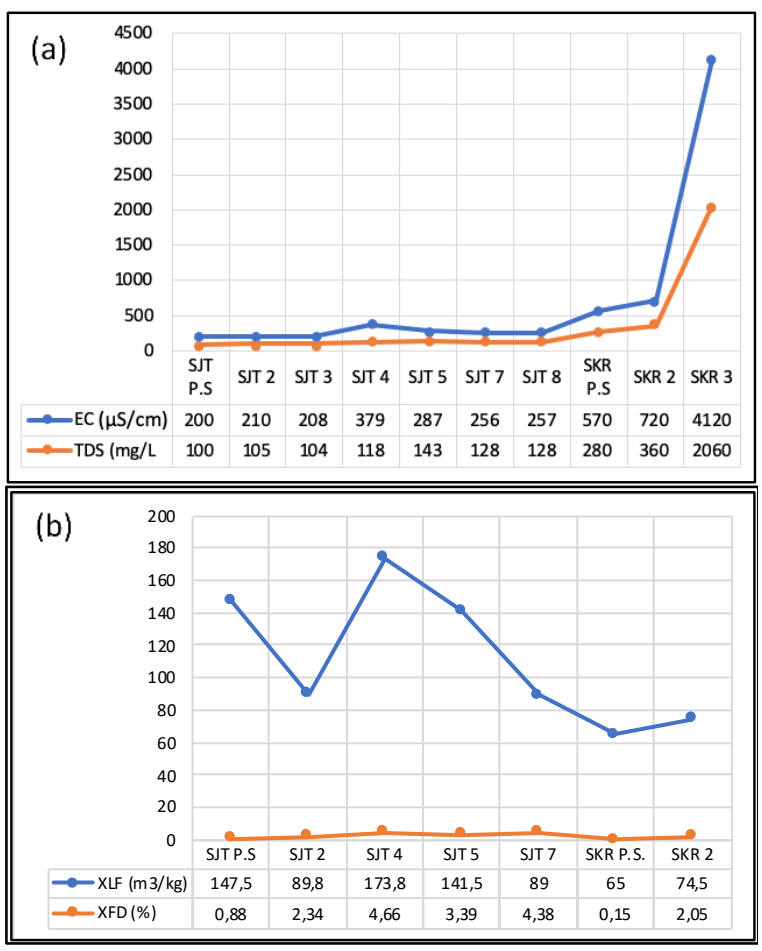

Gambar 3. (a) Perbandingan nilai EC dan TDS dan (b) perbandingan nilai $\chi_{\mathrm{LF}}$ dan $\chi_{\mathrm{FD}}(\%)$ dari lokasi awal pengambilan sampel hingga ke bagian hilir. 


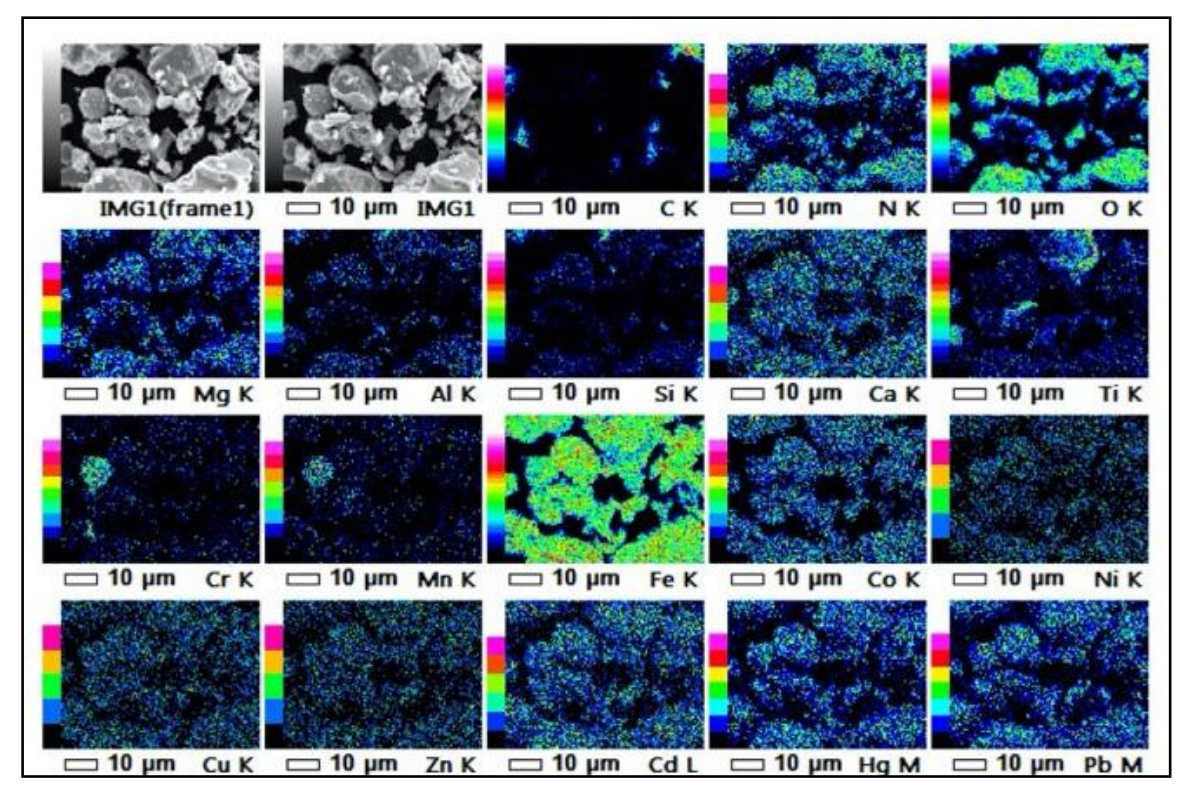

Gambar 4. Hasil pemetaan unsur pada sampel SJT P.S.

padahal pada bagian bawah ini terdapat daerah industri, hal ini dikarenakan batuan dasar pada Sungai Citarum berasal dari batuan vulkanik yang memiliki nilai $\chi_{\mathrm{LF}}$ yang cenderung besar [4].

Pengukuran uji analisis SEM-EDS yang dilakukan pada penelitian ini dapat memberikan informasi tentang morfologi mineral magnetik, ukuran bulir, dan pemetaan unsur yang diperoleh dari analisis pemindaian mikroskop elektron sampel yang dipilih. Gambar 4 menunjukkan hasil pemetaan unsur (elemental mapping) menggunakan SEM-EDS pada sampel SJT P.S. Sampel SJT P.S. merupakan sampel pada lokasi awal pengambilan sampel. Pemetaan elemen ini digunakan untuk melihat persebaran logam berat yang dominan pada sampel.

Pada hasil pemetaan terlihat bahwa logam besi (Fe) dan oksigen (O) terlihat paling terang warnanya yang menunjukkan dominasi unsur pada sampel SJT P.S. Hal ini diperkuat oleh hasil pengukuran XRD yang menunjukkan bahwa sampel didominasi oleh mineral magnetit $\left(\mathrm{Fe}_{3} \mathrm{O}_{4}\right.$ ) (Gambar 5). Kemudian ada kontribusi dari unsur lain seperti Titanium (Ti). Sampel sedimen yang mengandung sedikit Ti merupakan jenis mineral titanomagnetit hal tersebut juga sama seperti yang terjadi pada

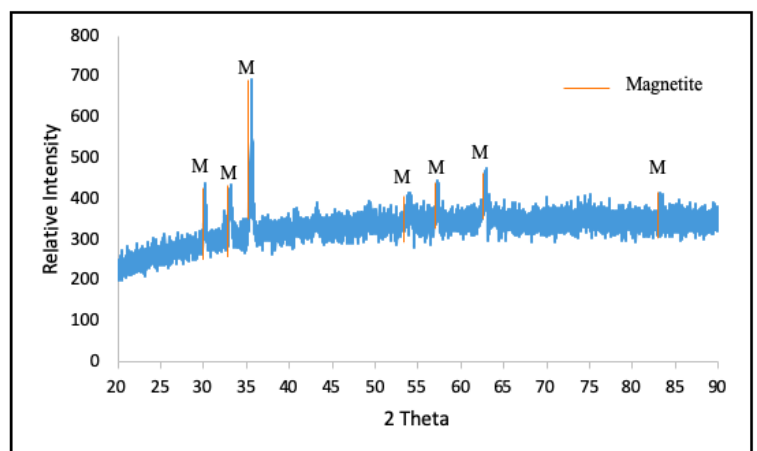

Gambar 5. Difraktogram sampel sedimen SJT P.S. sampel SJT P.S menunjukkan sedikitnya mineral Ti [28].

Hasil SEM-EDS pada Gambar 4 juga menunjukkan bahwa terdapat bulir magnetik yang berbetuk oktahedral yang merupakan bulir alami dari magnetit dan terdapat pula bulir berbentuk bulat (spherule) yang merupakan bulir magnetik akibat
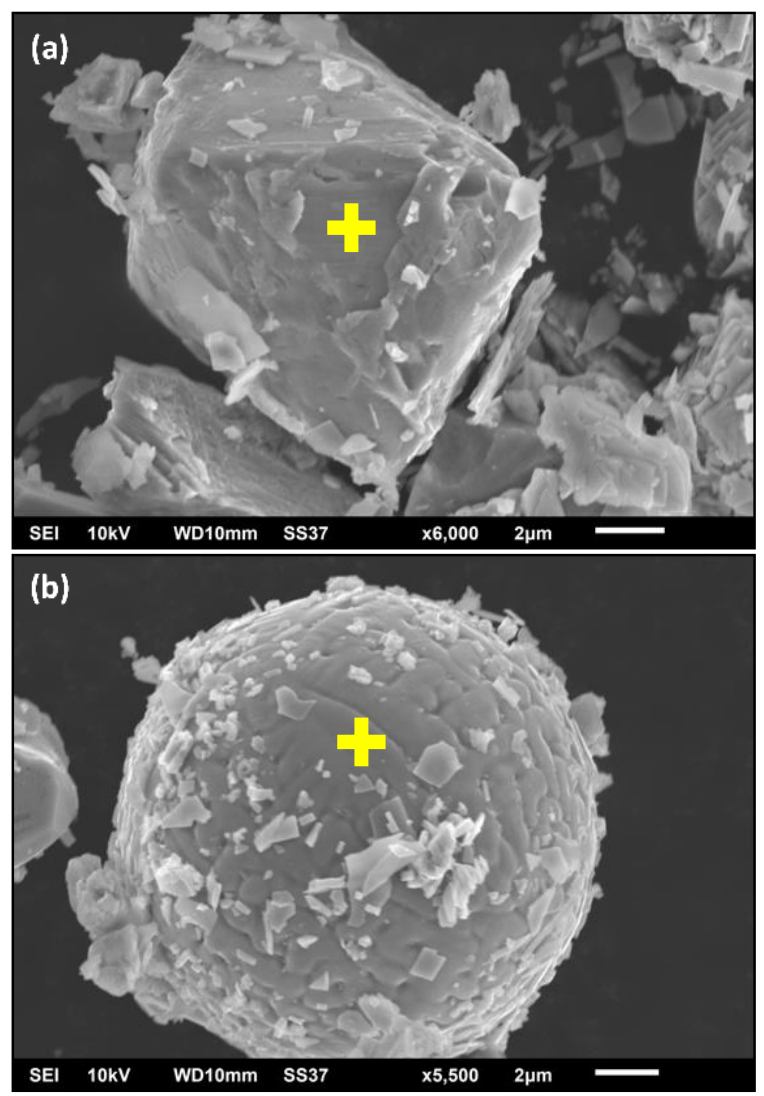

Gambar 6. Hasil Citra SEM-EDS sampel SJT P.S (a) menunjukkan bulir mineral magnetik berbentuk oktahedral (b) menunjukkan bulir mineral magnetik berbentuk spherule. 


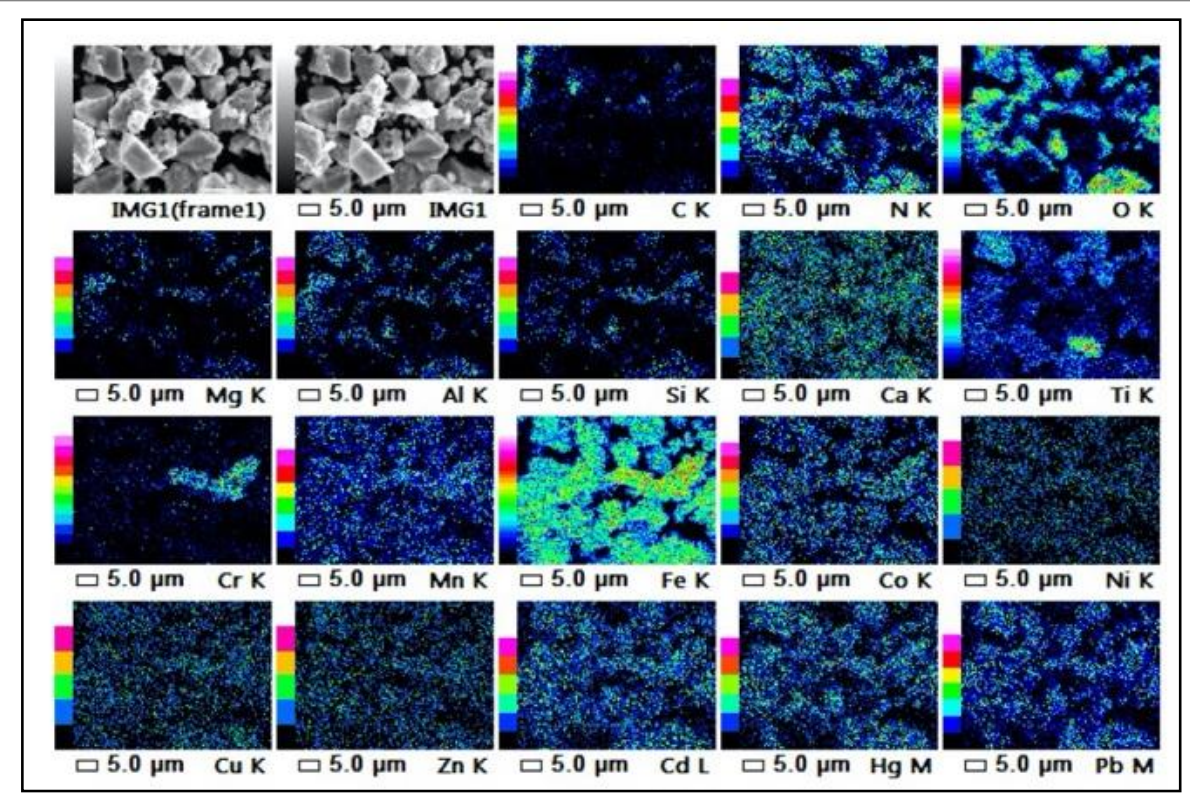

Gambar 7. Hasil pemetaan unsur pada sampel SKR 2

hasil oksidasi/pembakaran [29] dan proses diagenesis [30].

Hal ini sejalan dengan dengan diagram $\chi_{\mathrm{LF}}{ }^{-} \chi_{\mathrm{FD}}$ (\%) yang menyebutkan bahwa sampel-sampel berasal dari hasil pembakaran. Perbesaran bulir magnetik berbentuk oktahedral ditunjukkan pada Gambar 6 (a), sedangkan perbesaran bulir spherule ditunjukkan oleh Gambar 6 (b). Bulir mineral magnetik berbentuk sphrule juga ditemukan pada sedimen dibeberapa daerah penelitian, misalnya pada sedimen Sungai Danube [10]. Hasil SEM pada sedimen Sungai Danube menunjukkan adanya bulir mineral magnetik yang spherule sebagai tanda dari adanya sumber antropogenik. Bulir mineral magnetik yang berbentuk spherule diidentifikasi mengandung unsur logam berat kromium (Cr) dan mangan ( $\mathrm{Mn}$ ) lebih banyak dari pada bulir mineral magnetik berbentuk oktahedral (Gambar 4).

Selanjutnya, Gambar 7 menunjukkan hasil pemetaan unsur sampel SKR 2. Sampel SKR 2 merupakan sampel paling hilir. Dominasi unsur yang ada pada sampel adalah Fe dan O. Hal ini diperkuat dengan hasil pengukuran XRD pada Gambar 8. yang menunjukkan banyaknya mineral

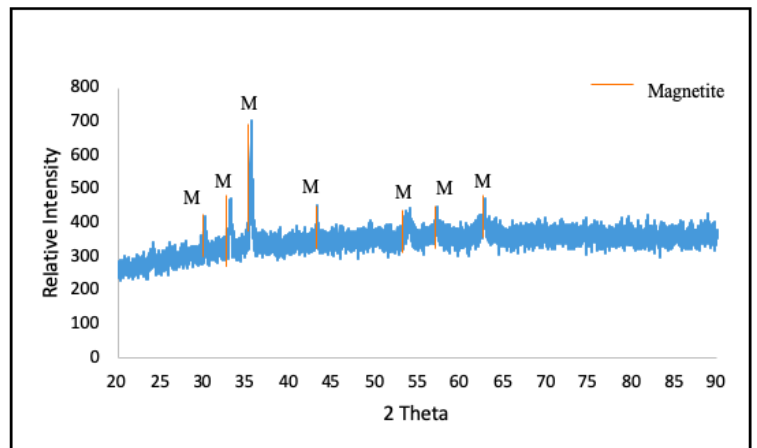

Gambar 8. Difraktogram sampel sedimen SKR. magnetit $\left(\mathrm{Fe}_{2} \mathrm{O}_{3}\right)$ pada sampel. Mineral magnetit pada sampel SKR 2 memiliki bentuk oktahedral dan spherule seperti ditunjukkan oleh Gambar 9. Mineral magnetik yang terdapat pada sampel SKR 2 memiliki beberapa unsur logam berat. Berdasarkan Gambar 7 dan Tabel 3, terlihat bahwa logam $\mathrm{Cr}$
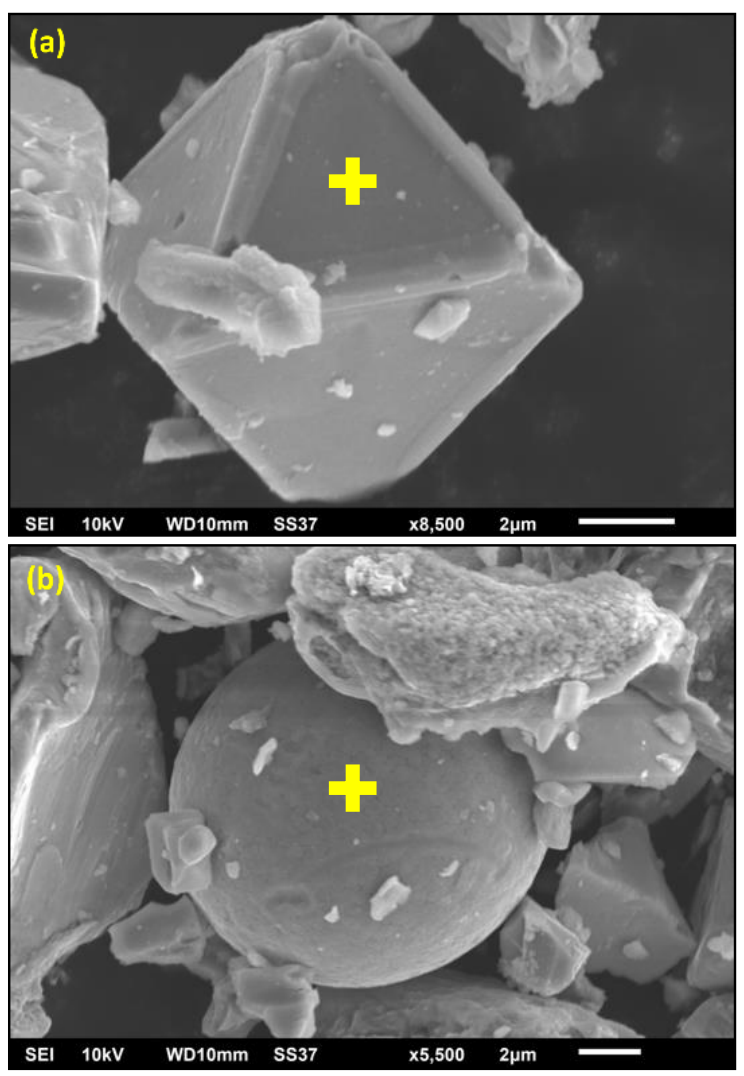

Gambar 9. Hasil Citra SEM-EDS sampel SKR 2 (a) menunjukkan bulir mineral magnetik berbentuk oktahedral (b) menunjukkan bulir mineral magnetik berbentuk spherule. 
POSITRON Vol. 10, No. 2 (2020), Hal. 131-139

Tabel 3. Analisis EDS mineral magnetik sampel SJT P.S. dan SKR 2

\begin{tabular}{|c|c|c|c|c|c|c|}
\hline \multirow{2}{*}{ Unsur } & \multicolumn{3}{|c|}{ \%Massa Sampel SJT P.S. } & \multicolumn{3}{|c|}{ \%Massa Sampel SKR 2} \\
\hline & Pemetaan & Oktahedral & Spherule & Pemetaan & Oktahedral & Spherule \\
\hline $\mathrm{C}$ & 19,37 & 4,79 & 6,31 & 12,39 & 15,50 & 4,32 \\
\hline $\mathrm{N}$ & 0,26 & - & - & 0,75 & 1,02 & - \\
\hline 0 & 37,31 & 39,85 & 45,46 & 31,21 & 48,36 & 35,81 \\
\hline $\mathrm{Mg}$ & 0,12 & 0,06 & 0,01 & 0,32 & 1,11 & 0,11 \\
\hline $\mathrm{Al}$ & 0,39 & 0,50 & 0,29 & 0,74 & 1,33 & 1,03 \\
\hline $\mathrm{Si}$ & 0,30 & 0,09 & - & 0,27 & 0,09 & 1,12 \\
\hline $\mathrm{Ca}$ & 0,02 & - & 0,02 & 0,03 & 0,02 & 0,12 \\
\hline $\mathrm{Ti}$ & 1,60 & 2,08 & 0,20 & 5,03 & 3,87 & 0,47 \\
\hline $\mathrm{Cr}$ & 0,35 & 0,10 & 0,03 & 1,04 & 0,14 & 0,14 \\
\hline $\mathrm{Mn}$ & 0,30 & 0,21 & 0,25 & 0,35 & 0,14 & 0,02 \\
\hline $\mathrm{Fe}$ & 38,74 & 50,69 & 46,11 & 46,22 & 27,22 & 55,34 \\
\hline Co & 0,19 & 0,33 & 0,10 & 0,14 & 0,22 & 0,28 \\
\hline $\mathrm{Ni}$ & 0,04 & 0,02 & 0,10 & - & - & - \\
\hline $\mathrm{Cu}$ & 0,50 & 0,47 & 0,50 & 0,77 & 0,50 & 0,71 \\
\hline $\mathrm{Zn}$ & 0,46 & 0,56 & 0,44 & 0,72 & 0,47 & 0,54 \\
\hline $\mathrm{Cd}$ & - & 0,04 & 0,09 & - & 0,01 & - \\
\hline $\mathrm{Pb}$ & 0,04 & 0,24 & 0,07 & - & - & - \\
\hline Total & 100 & 100 & 100 & 100 & 100 & 100 \\
\hline
\end{tabular}

menunjukkan kontribusi yang lebih banyak dibanding dengan logam yang lainnya (tembaga $(\mathrm{Cu})$, seng $(\mathrm{Zn}), \mathrm{Mn})$. Unsur $\mathrm{Cr}$ banyak digunakan dalam proses industri dan juga sebagai hasil dari aktivitas antropogenik [31], sedangkan Mn merupakan hasil dari aktivitas limbah pertanian berupa penggunaan pupuk [32] atau penggunaan pestisida [33]. Daerah yang dilalui oleh aliran air Sungai Citarum bagian hilir yaitu daerah industri di Kabupaten Karawang dan Kota Bekasi dan daerah pertanian di Kabupaten Karawang, sehingga bukan tidak mungkin, material antropogenik dapat masuk ke dalam Sungai Citarum.

Adapun hasil pengukuran EDS mengenai kandungan unsur atau fraksi massa dari pemetaan unsur, bulir oktahedral, dan bulir spherule disajikan pada Tabel 3. Berdasarkan analisis morfologi dari pengukuran SEM-EDS dan analisis mineralogi dari pengukuran XRD diindikasikan adanya material antropogenik pada sampel sedimen yang dapat mencemari lingkungan Sungai Citarum bagian hilir. Bentuk bulir spherule sebagai ciri adanya material antropogenik juga dijumpai pada sampel sedimen sungai lain misalnya Sungai Danube, Jerman [10] dan Sungai Dobra, Kroasia [34].

\section{Kesimpulan}

Berdasarkan pengukuran sifat fisika dan kimia air Sungai Citarum mengindikasikan bahwa air Sungai Citarum memiliki EC, TDS, pH, dan suhu di bawah ambang batas yang diperbolehkan. Namun demikian, perlu dilakukan pemantauan secara berkala dan berkelanjutan terhadap kualitas air Sungai Citarum.

Karakterisasi mineral magnetik berdasarkan pengukuran suseptibilitas magnetik menunjukkan bahwa pada sampel sedimen Sungai Citarum bagian hilir terdapat bulir halus magnetit yang mengindikasikan hadirnya material antropogenik. Hasil ini diperkuat dengan analisis morfologi dari citra SEM-EDS dan analisis mineralogi berdasarkan pengukuran EDS. Dominasi jenis mineral magnetik pada sampel sedimen adalah magnetit. Mineral ini memiliki morfologi berbentuk oktahedral sebagai representasi mineral magnetik alami dan ada pula yang berbentuk spherule sebagai representasi mineral magnetik karena adanya proses oksidasi akibat kehadiran material antropogenik pada sedimen Sungai Citarum bagian hilir.

\section{Ucapan Terima Kasih}

Terima kasih kepada Universitas Padjadjaran yang telah memberikan dukungan materil berupa Hibah Internal Unpad (HIU) dengan skema Riset Kompetisi Dasar Unggulan (RKDU) kepada KHK. Terima kasih juga kepada Prof. Satria Bijaksana atas izin menggunakan peralatan laboratorium karakterisasi sifat fisis batuan FTTM ITB.

\section{Daftar Pustaka}

[1] Bukit, N. T. dan Yusuf, I. A., Beban Pencemaran Limbah Industri Dan Status Kualitas Air Sungai Citarum, Jurnal Teknologi Lingkungan, 3(2), pp. 98-106, 2002.

[2] Happy R. A., Masyamsir dan Dhahiyat, Y., Distribusi Kandungan Logam Berat $\mathrm{Pb}$ dan $\mathrm{Cd}$ Pada Kolom Air Dan Sedimen Daerah Aliran Sungai Citarum Hulu, Jurnal Perikanan dan Kelautan, 3(3), pp. 175-182, 2012.

[3] Ilyas, M. A., Sedimentasi dan dampaknya pada DAS Citarum Hulu, Jurnal Teknologi Lingkungan, 3(2), 159-164, 2002. 
[4] Sudarningsih, S., Bijaksana, S., Ramdani, R., Hafidz, A., Pratama, A., Widodo, W., Iskandar, I., Dahrin, D., Fajar, S. J., dan Santoso, N. A., Variations in the concentration of magnetic minerals and heavy metals in suspended sediments from citarum river and its tributaries, West Java, Indonesia, Geosciences, 7(3), pp. 1-13, 2017.

[5] Bityukova, L., Scholger, R., dan Birke, M., Magnetic susceptibility as indicator of environmental pollution of soils in Tallinn, Physics and Chemistry of the Earth, Part A: Solid Earth and Geodesy, 24(9), pp. 829-835, 1999.

[6] Pan, H. , Lu, X. , Lei, K. , Shi, D. , Ren, C. , Yang, L., dan Wang, L. , Using magnetic susceptibility to evaluate pollution status of the sediment for a typical reservoir in northwestern China, Environmental Science and Pollution Research, 26(3), pp. 3019-3032, 2019.

[7] Yunginger, R., Bijaksana, S., Dahrin, D., Zulaikah, S., Hafidz, A., Kirana, K. H., Sudarningsih, S., Mariyanto, M., dan Fajar, S. J., Lithogenic and anthropogenic components in surface sediments from lake limboto as shown by magnetic mineral characteristics, trace metals, and REE geochemistry, Geosciences, 8(116), pp. 1-11, 2018.

[8] Vitousek, P. M., Mooney, H. A., Lubchenco, J., dan Melillo, J. M., Human domination of Earth's ecosystems, Science, 277(5325), pp. 494-499, 1997.

[9] Kirana, K. H., Fitriani, D., Supriyana, E., dan Agustine, E., Sifat Magnetik Sedimen Sungai Sebagai Indikator Pencemaran (Studi Kasus : Sungai Citarum Kabupaten Karawang), Jurnal Spektra, 15(2), pp.99-101, 2014.

[10] Jordanova, D., Hoffmann, V., dan Fehr, K. T., Mineral magnetic characterization of anthropogenic magnetic phases in the Danube river sediments (Bulgarian part), Earth and Planetary Science Letters, 221, pp. 71-89, 2004.

[11] Orosun, M. M., Oniku, S. A., Peter, A., Orosun, R. O., Salawu, N. B., dan Hitler, L., Magnetic susceptibility measurement and heavy metal pollution at an automobile station in Ilorin, North-Central Nigeria, Environmental Research Communications, 2(015001), pp. 19, 2020.

[12] Strzyszcz, Z., A., Magiera, T. dan Heller, F., The influence of industrial immisions on the magnetic susceptibility of soils in upper Silesia, 40, pp. 276-286, 1996.
[13] Mariyanto, M., Amir, M. F., Utama, W., Hamdan, A. M., Bijaksana, S., Pratama, A., Yunginger, R., dan Sudarningsih, S., Heavy metal contents and magnetic properties of surface sediments in volcanic and tropical environment from Brantas River, Jawa Timur Province, Indonesia, Science of the Total Environment, 675, pp. 632-641, 2019.

[14] Devanesan, E., Chandrasekaran, A. , Sivakumar, S., Freny Joy, K. M., Najam, L. A., dan Ravisankar, R., Magnetic Susceptibility as Proxy for Heavy Metal Pollution Detection in Sediment, Iranian Journal of Science and Technology, Transaction A: Science, 44, pp. 875-888, 2020.

[15] Petrovský, E., Kapička, A., Jordanova, N., Knab, M., dan Hoffmann, V., Low-field magnetic susceptibility: A proxy method of estimating increased pollution of different environmental systems, Environmental Geology, 39(3-4), pp. 312-318, 2000.

[16] Kind, J., Raden, U. J. V., García-Rubio, I., dan Gehring, A. U., Rock magnetic techniques complemented by ferromagnetic resonance spectroscopy to analyse a sediment record, Geophysical Journal International, 191(1), pp. 51-63, 2012.

[17] Marandi, A., Polikarpus, M., dan Jõeleht, A., A new approach for describing the relationship between electrical conductivity and major anion concentration in natural waters, Applied Geochemistry, 38, pp. 103-109, 2013.

[18] Sudarningsih, S., Maulana, L., Bijaksana, S., Hafidz, A., Pratama, A., Widodo, W. dan Iskandar, I., Magnetic characterization of sand and boulder samples from citarum river and their origin, Journal of Mathematical and Fundamental Sciences, 49(2), pp. 116-126, 2017.

[19] Dearing, J. A., Environmental Magnetic Susceptibility: using the Bartington MS2 System, 2nd ed., Chi Pub. Kenilworth, pp. 1-54, 1999.

[20] Novala, G. C., Sudarningsih, Kirana, K. H., Fajar, S. J., Mariyanto, dan Bijaksana, S., Testing the effectiveness of mechanical magnetic extraction in riverine and lacustrine sediments, Journal of Physics: Conference Series, 1204(012085), pp. 1-8, 2019.

[21] Rusydi, A. F., Correlation between conductivity and total dissolved solid in various type of water: A review, IOP Conf. Series: Earth Environ. Sci., 118(012019), pp. 1-6, 2018. 
[22] WHO, Guidelines for Drinking-water Quality, $3^{\text {rd }}$ ed., 1, WHO Library Cataloguing, pp. 1-515, 2008.

[23] Kementerian Kesehatan Republik Indonesia, Peraturan Menteri Kesehatan Republik Indonesia Nomor 32 Tahun 2017 tentang Standar Baku Mutu kesehatan Lingkungan dan Persyaratan Kesehatan Air untuk Keperluan Higiene Sanitasi, Kolam Renang, Solus Per Aqua, dan Pemandian Umum, pp. 1-31, 2017.

[24] Solomon, J. S., Ahmed, A. L., Adamu, I. H. dan Dimu, 0. O., Identifying Anthropogenic Metallic Pollutants Using Frequency Dependent Magnetic Susceptibility, Current Trends in Natural Sciences, 6(11), pp. 13-22, 2017.

[25] Bijaksana, S. dan Huliselan, E. K. , Magnetic properties and heavy metal content of sanitary leachate sludge in two landfill sites near Bandung, Indonesia, Environmental Earth Sciences, 60(2), pp. 409-419, 2010.

[26] Juliansyah, A., Zulaikah, S., Mufti, N., Agustin, E. Y., Pujiastuti, R. dan Iswanto, B. H., Magnetic susceptibility of river sediment in polluted area of traditional gold mining in Kuris Sumbawa Indonesia, AIP Conference Proceedings, 2251(040020), pp. 1-5, 2020.

[27] Chaparro, M. A. E., Suresh, G., Chaparro, M. A. E., Ramasamy, V. dan Sinito, A. M., Magnetic studies and elemental analysis of river sediments: A case study from the Ponnaiyar River (Southeastern India), Environmental Earth Sciences, 70(1), pp. 201-203, 2013.

[28] Tamuntuan, G., Bijaksana, S., Gaffar, E., Russell, J., Safiuddin, L. O. dan Huliselan, E., The magnetic properties of Indonesian Lake Sediment: A case study of a tectonic lake in South Sulawesi and maar lakes in East Java, ITB Journal of Science, 42(1), pp. 31-48, 2010.
[29] Huliselan, E. K., Bijaksana, S., Srigutomo, W. dan Kardena, E., Scanning electron microscopy and magnetic characterization of iron oxides in solid waste landfill leachate, Journal of Hazardous Materials, 179(1-3), pp. 701-708, 2010.

[30] Liu, Q., Roberts, A. P., Larrasoaa, J. C., Banerjee, S. K., Guyodo, Y., Tauxe, L. dan Oldfield, F., Environmental magnetism: Principles and applications, Reviews of Geophysics, 50(4), pp. 1-50, 2012.

[31] Bourliva, A., Kantiranis, N., Papadopoulou, L., Aidona, E., Christoforidis, C. dan Kollias, P., On the morphology, geochemical characteristics and magnetic properties of urban road dust particles from the historic center of the city of Thessaloniki, Greece, Proceedings of the 12th international conference on environmental science and technology, Rhodes, Greece, 8-10 September, pp. 238-245, 2011.

[32] Chakarvorty, M., Dwivedi, A. K., Shukla, A. D., Kumar, S., Niyogi, A., Usmani, M. dan Pati, J. K., Geochemistry and magnetic measurements of suspended sediment in urban sewage water vis-à-vis quantification of heavy metal pollution in Ganga and Yamuna Rivers, India, Environmental Monitoring and Assessment, 187(604), pp. 1-17, 2015.

[33] Harris, E. S. J., Cao, S., Littlefield, B. A., Craycroft, J. A., Scholten, R., Kaptchuk, T., Fu, Y., Wang, W., Liu, Y., Chen, H., Zhao, Z., Clardy, J., Woolf, A. D. dan Eisenberg, D. M., Heavy metal and pesticide content in commonly prescribed individual raw Chinese Herbal Medicines, Science of the Total Environment, 409(20), pp. 4297-4305, 2011.

[34] Frančiškovic-Bilinski, S., Bilinski, H., Scholger, R., Tomašić, N. dan Maldini, K., Magnetic spherules in sediments of the karstic Dobra River (Croatia), Journal of Soils and Sediments, 14(3), pp. 600-614, 2014. 